\title{
Representatives of Verism in the Albanian Prose Issued in Totalitarism in Albania
}

\author{
Dr. Luljeta Bora
}

\author{
Doi:10.5901/jesr.2013.v3n7p408
}

\section{Abstract}

The only written model framed among the features of the verism in the Albanian literature is the Teodor Keko's (1958-2002) work as a prose, a literature now ended with the author's death. When Teodor Keko started to give to his prose full verist features, the Albanian literature was still facing problems with its development in the branch of the realism-socialist method, a method which forcefully got trumpeted from the politics of the time. We think that $T$. Keko could have had knowledge on the Italian Verism of the end of the XIX century, that comes as a branch of naturalism, but what we believe and verify in his art is that this literary direction does not come to Keko as something looked for, or as an ordinary imitation, but as an urge, an initiative that could be defined as a revolt, an artistic challenge of his toward the false spirit of the art of that time. But which are some of these original features of his work that bring it so close to the Italian verist art?Firstly "the surveillance camera" of Keko looks for the unclean and his art is "uncombed", with lots of street subjects. Keko's heroes represent with themselves the model of an anti-hero. Deepen in the apathy of life and the wrong choices they have nothing to be commented about, to be taken as an example, nothing heroic. They are characterized as marginal, suburban characters. Secondly: They (the characters) and the subject lines, mainly aim the lively truthfulness. They are as real and reliable just like Kapuna's, Verge's characters that they seem as if they have been taken out of a same reality, it looks like these kind of people came into you on the street. Thirdly: Their language is that of the street that ensures the truthfulness and Keko, just like the verist writers, is seen nowhere, it seems like the characters speak themselves as taken out of the real life.

The Albanian literature has got representatives of different literary directions, but a little seen in it is the representation of the verism feature and this work aims surveys upon this feature in the contemporary Albanian prose.

The author, who could for sure be considered as a rare representative of verism in the Albanian letters (if not the only one) is Teodor Keko (1958-2002).

Various scholars ${ }^{1}$ acknowledge that it has never happened that the Albanian literature lead literary directions that have not bloomed yet in other countries. On the contrary, many literary directions have not reached to bloom at all, whereas others (classicism, romantism, realism, modernism...) have sprung very late. On the other hand based on the conversations with the author's friends and scholars it has been given evidence that Teodor Keko was not aware of Verism as a literary direction and nonetheless had pure knowledge on the literature of all the authors part of this direction.

The question arouses naturally: How come that full features of this direction are seen in the author's prose? Which were the consequences that brought so naturally the art of this author next to Verism during the years of dictatorship?

Son of two moviemakers, graduated for literature in Tirana University, journalist in profession, Teodor Keko everyday touches the poor Albanian reality. He is not attracted to the swollen model of the socialist literature of that time and feels the need to make part of his prose exactly this sad and empathic reality.

The scholar Floresha Dado notices that 'The history of the literary development has witnessed that a literary direction arouses in a specific period of time, blooms according to the social cultural circumstances and it is replaced from another direction because of changes that happen in the spiritual life of the society' (Dado 2010)

Having in mind the author's words in interviews we judge that Verism has come up naturally in his prose as an artistic revolt.

When we set this author apart as one of the unique representatives of verism we firstly have in mind that the feature of belonging to this literary direction in him is very prominent and it does not appear as something asked for, as an imitation, but as an unrepeatable art, first created from an individual prospect melted with a content, and with a very special object construction, that is at the same time a very special way of making art.

Before we move on with arguments about his art concordance with that of the verism needs to be pointed out that it is not easy to categorize his art as loyal to an only literary direction, for he penetrates through some literary schools by so being a very original art for the Albanian letters.

${ }^{1}$ Look at Academic F.Dado "Non-interpreted literature", Albanian world, Tiranë 2010, Ymer Çiraku"Critical examinations from the history of the Albanian literature", Albas, Tiranë2011 
Firstly: he reflects nothing from the method of the socialist realism even though he wrote at a time when this method was widely used. So we find in him neither a positive hero, nor an ideological spirit, neither a popular spirit, nor a reflection of the revolutionary development of life or other principals that in the gist destroyed art. T. Keko's art comes as a full opposing conscience, testimony that we get from the data that are found from the interviews he had from the press of that time or from testimonial facts of the life shown in the work of art 'Ditet e jetes sime' ("The days of my life"), of the film producer Xhanfize Keko (his mother).

Secondly: Keko's art has got realistic inclination². He is distinguished about a reflection with loyalty to the Albanian reality of the 80's-90's; two systems, two different worlds with the abyss of total bewilderment in the middle, people in need, anger of discontent. His confession makes an autopsy to the reality of the time. If we refer to the work of art " Sociologia della litteratura", he becomes a social thermometer "( Alfredo Luzi, Letture critiche,"Sociologia della letterature", second edition, ,"Mursia",pg 109...the narrative results as an effecient thermometer, sometimes even from its own shape, to understand the spirit that circulates the social net; a sustain of the imaginary univers upon the sociologic researches that would be needed to search in the real univers...... On the other hand literature as an autonomous work of the individ and the individ as an expression of a social group welcomes totally the affective and intellectual life of the writer and the social group in which the writer as part of it is an element of the readers(my translation. L.Bora)". So they are the features that hold works of realism of the XIX century. Indeed when the author focuses deep in psychological analyses as in the story 'E huaj'("Stranger"), or his narrations 'Lumturi me vel te zi' ("Happiness with black veil"), 'Lajmetarja e vdekjeve' ("The death messenger") etc, which are rich in social analyses, the realism shown there gets the features of a psychological realism.

About his first work with stories 'Lajmetarja e vdekjeve'(“The death messenger”), Keko says that it comes as a combination of realism and romanticism ${ }^{3}$. Perhaps when the author defines the romantic nature of the work has in mind some prose (a small number in fact), mainly short where you find happy endings, where the main character develops by greatly improving in a negative way, or where it is clearly seen the moral character for example at the ends of the prose in which they show a cliché(fixed shape) of the triumph of good upon evil, but in the shape of an ending where everything goes as it should which we find in the prose: 'Karamelet'( "The candies"), 'Kepuca e zgjidhur' ("The untied shoe") or the story 'Shtepite ne oborr' ("The houses in the yard").

Thirdly: Teodor Keko's art, apart from an effort to take the subject from the reality, leans toward a simplified reality through a detailed description, almost in scientific details of the psychological world and frame of mind, of a specific culture of the Albanian of the period of time during 80's-90's, which would match with the explanation of human beings in a triple unity: race, environment, moment that we would find at the naturalists of the XIX century like Flober, Dickens, etc (but at T. Keko we don't find anything from the prospective of the positive hero facing the negative, or Dicken's moralizing tendency).

The naturalists' art, influenced by the positivism was about a necessity of the objective reproduction of life, among a severe implementation of the non-interference of the observer in the objects of the artistic observation. The naturalists prefer the presentation of the non-typical characters, unimportant, in a very spontaneous mood, occasional scenes filled with incorrect grammatical usages and with trivial expressions.

It is very obvious in Keko's prose his attention toward the suburban society, the invisible man in the hectic swirl of life, known differently as the 'marginal man'4. This attention is an early one and should be understood as a fatigue from the heroes of the works who followed the flow of the method of the socialist realism (that in fact there is no realism at all, but only artificial artistic spirit blended with meaningless ideology). Keko appraised the Albanian novel of that time as 'empty and without life' and his character 'bird of incubator' ${ }^{5}$. He looks somewhere else, at the streets, in the neighborhoods, at the corners where another life rushes, naked, far away from the 'positive hero', far from the polishes and overstatements for the intellectual hero, who 'engages in abstract speculations and sits idle on an empty stomach' 6

The work as a journalist gave Keko the opportunity to get to know with many people from different levels of the society, among them ordinary people, to whom not only paid his attention but also the his human respect. All of his life

\footnotetext{
${ }^{2}$ Realism - literary direction, predominant in the XIX century literature. Object of the work of art became reality. Everything was taken from the real life and resembled it. The realist writers treated the reality with the preciseness and the objectivity of the positive sciences and in many occasions they illustrated the ideology and philosophy of the time with their works.

3 "R.D" newspaper, 22 March 1998

4 Philosophy dictionary, "Toena", Tiranë 2007, Marghine-marginal (margo-end, side) Marginal, what is found in margins, at ends, aside, as unimportant and not essential, secondary, peripheral

5 "Shekulli" newspaper, 11 July 1999, pg 18, With the reader you should be real

6 "R,D" newspaper, 22 March 1998.(Today we are still in the Medieval, interview)
} 
experience, as well as these ordinary men became part of his work. If you look at it in a specific point of view it seems as this inclusive phenomenon in Keko impoverishes the literary, but in fact it does not. Through that another color of the literary is profited, a totally different literary model, which he creates consciously aiming the vitality and the separation from the inanimate person of our literature until then. Following this logic, the interpretation and the treating of the values of his art form us will be upon this coloring of a new reality to the majority of these human beings, a literary reality different for the time being.

Keko's art does not find spots of meeting in a horizontal plan with the literature of the prose writers, but in a vertical plan, the only written literary model with which you can find common spots is the model brought by Migjeni ${ }^{7}$ with his fatal literature in prose and with the attention toward the suffering individual and in the reality of the bewilderment of the values of a lying moral of the 30's. Keko's eye notices the hidden corners and nooks of the city, usually the 'unclean', what is not noticed, sometimes the ordinary in human beings, a multiple tiny things, that surprises you how someone can make art with them.

Keko's hero (that in fact is an antihero) is not commendable in values and virtues. There is nothing of heroic within the characters of his prose. This kind of character is not prominent and there is nothing obvious to be taken as an example. He is a model who fights the hero and the values. The characters recognize the mistake, submit to the temptation of the habit, many of them are portrayed 'as a black catalogue of definitions' (if we would use a categorizing of the author). These characters do not change the reality. They are weak even if we would not want this. They try to survive with less pain in a baffled reality. One thing is certain. This prose overfilled with marginal types would not be able to ever be published in that system that fearfully aimed heroic and muscular types of the volunteer work.

A very good number of T. Keko's characters are characterized as illustrations of workers or unemployed people, youngsters who spend their time in vain, waiters, barmen, students in search of a seasonal job, abandoned elders that mainly get angry rather than being touched from each-other's death, abandoned grandparents, failed parents, desperate widows full of sensuality, ordinary women exploited by criminal males, villager women who dread themselves all day long in the fields, thirsty provincial for noisy life, lying children, physical handicapped people, unimportant civil employees, journalists, unskillful doctors, prostitutes (in spirit and because of problems), immoral men, drunk men, refugees and so many more characters, who you can see on the street in a very ordinary day.

\begin{abstract}
".......miserable period for the four of us that are resting on the banisters of the big bridge, where a series of roads are crossed..... There will be no walking today and stupid women who pretend to have gone out for fresh air up and down the boulevard and they merely breathe with all of their lung capacity the cancer air provided by the oil-fired boilers full of coking coal smoke of the ministers' cars. Filthy period for Kol the dental doctor, that time after time yawns with sleep, the same for Tur the plumber, who sniffs like a hunting dog those disoriented junior students who spends the half of the day at the beginning of school seasons sat at the pavements of the addresses office, bad for me, the student of the last year for linguistic and literature, with no expression for Gon the economist, permanent autumn...." (Keko 1991)
\end{abstract}

Keko introduces the characters very simple and accepts them as they are. In the narrations that refer to a reality of the dictatorship period, you find some peripheral figures dressed in remote brutality, types in whose mouth he mocks the socialist reality and the ridiculous ideological manner in which the things work.

Some comic figures are interesting, in the limits of caricature, and moreover characterized in the street slang that insert in certain fragments expressions with which it is impossible to not laugh. They are so exaggerated and natural at the same time. A density of this kind of characters was not preferred to be inserted in art not only in the socialist realism of literature but even later in the Albanian literature. His characters are mainly found amid the detailed descriptions of the moods, moments, empathies, sacrifices, facing of the reality, of thousands unimportant pettiness. Keiko's work deeply leads the naturalism toward verism.

The Italian verism, a literature school of the late XIX century that comes as a branching of naturalism, also has elements of the critical realism. Its representatives like Verga, Kapuana and Maxoni tried to picture the reality with all its ugly and banal aspects.

"According to Verga, the artistic performance should have 'the power and value of being like that'. It should give to the narration the intonation, expression, style and the shape of an event which really happened. It should bring human documents for this, so, evidence of the events. But on the other hand it is not enough for the event to be told and documented, it should be real. It should be narrated in that way that the reader faces the clear fact without connotations and not to have the impression that he/she is seeing the event through 'the writer's lenses'. To fulfill this, the writer

\footnotetext{
${ }^{7}$ Migjeni(Millosh Gjergj Nikolla(1911-1938), wrote the realistic literature. His characters are very simple people in existencial sufferings, in dilema, with no choice.
} 
If the Italian verists reflected the southern reality through their art, poor, characters in enormous economical-moral dramas, Keiko tried to reflect a urban society, (where the toponymy of Tirana and its surrounding is mainly seen) in everyday living style, by artistically fulfilling fates and frames of mind to a multiple unsatisfied characters.

Just like the verists in their works even Keko gives the view of an ignorant reality, left aside from the political sphere. As a scientist he searches consequences that bring ugly features or features of the fates and the frames of mind to a series of separate characters, by giving an important contribute to the direction of the observing eye upon these people within who you find no optimism. His prose, as well as in the verists', moves with agility within the master combination of dialogues with high and simple tones that characterize the thoughts of a series of peripheral figures which are often found within the expressions of the comic situations.

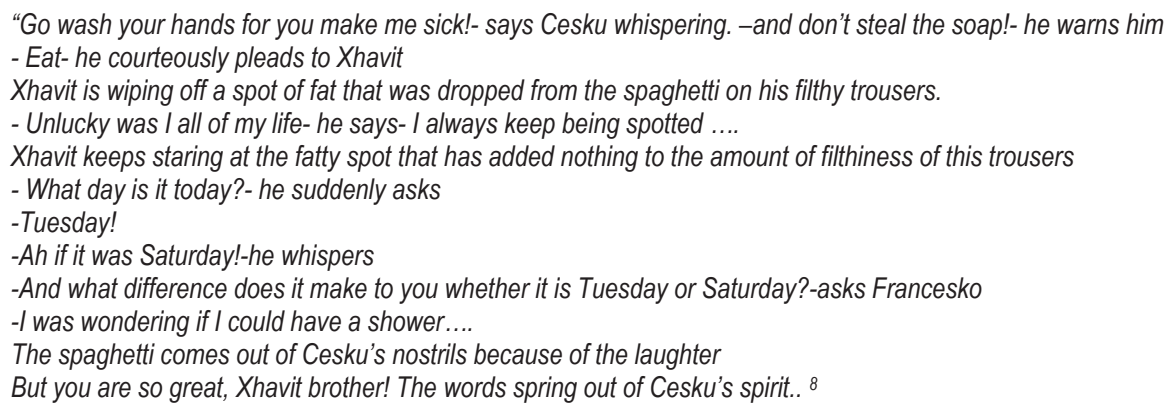

Sometimes the readers are faced to fatal situations, or to extreme sufferings, like for example in the prose 'Qiejt e vetmise'( "The skies of loneliness"), or 'Muhamedi' ("Mohamed") typical of the skapilaturists' art, but in Keko's we do not find the combination with the fantastic and at the same time we do not see the narration in the first person as a tendency. ${ }^{9}$

Keko introduces very simple his characters and he accepts them as they are. He puts his readers in front of truthful situations, which he judges with his characters' mouths, with a logical reasoning that perfectly fits them, 'gets in the skin' of their lively experience and points out through a popular and slang language simple judgments and conclusions that often become simplified philosophical thoughts that come as a result not only to a lively experience but even to a very sharp observing eye. These characters become more attractive to the reader where the life conclusion comes up from a 'catastrophic' dictionary that works in double meanings.

'....the pleasure wants the stomach full. I am not hungry anymore'; says a cleaning lady implying the sexual desire that passes with the age. 'In this shitty world where nothing ever changes, where you precisely know what tomorrow is going to happen, you have lost nothing!'; philosophizes an alcoholic patient who has spent all of his life in the prison of communism.

The simplified speech, defined as 'vulgar', deforming, degraded, destroyable to art, unacceptable for the literature, in Keiko's prose, it only becomes a mean that emphasizes the truthfulness of the character, an expressive mean of originality color of the art and the meaningfulness of the word. So in T.Keko the slang turns into an artistic typically mean.

The language of Keko's characters is the conversational one and it is impossible to not notice that this author will definitely master of the slang speech ${ }^{10}$ in the Albanian literature. This pure slang language ignores the official literary and it is not a coincidence, but a fact of the author's choice for a social truthfulness and a sound coloring that would perfectly fit the type of his peripheral characters.

\footnotetext{
8 T.Keko, 12 saints, one profet and some people, the narration"Always on 28 November",pg 151-152

9 Dictionary Itaian-Albanian, shb "Eurolindja", Tiranë'96, pg 969. Scapiglatura-shtyrje, hideous life. Scapigliaturisti- skapilaturistët, milanist, deep realists, individuals who lived in black people gettos. They reflected realistic backgrounds, passionat stories are alternated with fantastic extraordinary confessions upon evil subjects,scary, within extreme situations, extraordinary, sensual and destroying passions, diseases, delir.

${ }^{10}$ Explaining dictionary of the literary expressions,Tiranë 1972, pg 152, ZHARGON(fr,jargon)- popular speech, original speech, conventional, group of words and special expressions which are used by a social group, or mob of people(slang of bricklayers, thieves, aristokracy.....the slang makes the language a bastard, its usage in an artistic-literary work is justified only in those occasions when it is useful to give the characteristical speech of the character.
} 
The spotting of the characters, among all other things, is made upon this language, which sometimes is intertwined with a poetic speech of the author, which is prominent through a slang description and sometimes slips in speech formats that would be defined as shameful. Starting form the second work in prose 'Lajmetarja e vdekjeve' ("The death messenger"), Keko's characters use slang. We see the street slang, the lexicon of an untamed brutal, of the drunk, of the street wanderer, of a prostitute, of a student, etc, etc. Keko himself declares in an interview that in the work 'Lajmetarja e vdekjes'("The death messenger") for the first time teems the way of speaking in ' $80^{11}$

The characters' speech is within a typical slang by setting it aside as a character model. It is exactly the worker's and the intellectual's language, which differ from one another from the stages of inserting ordinary daily words in their speech. The characters' speech is what we usually hear. It becomes so clear through a verist tendency that it looks like as the narrations are self-made, like the characters are taken out of lively situations, and behind them it does not stand the author but themselves. From the other hand, this speech option fits to the dimness of the reality colors and Keko's unwillingness to look at it differently as many other authors did at his time. In fact this tendency has been a missing value in the Albanian literature. We define it a value, because in the role of the value we find it in T. Keko. It gives to its art the truthfulness and the original. This slang, part of his art, created by street subjects filled with vulgarism, makes the character as one apart from the reality. These characters mainly have something of gypsy in the banal way how they ignore the reality and fit to the situation. Such a way of treatment gives them the strength to survive and makes them totally confident. But the fulfillment of the speech in the simplified way of speaking does not simply understand the banality of the street subject, because in this speech you notice the text and the subtext. There is art in finding the proper word in order to give shades of meanings.

In the idiolect word we find two realities: that of the main understanding and that of the coloring. This coloring put on a slang bed is distant with the metaphorical coloring in the literary speech, so it is not that obvious, but it is felt. So the idiolects create a new reality of the word and they become influencing to the reader's reality. In the characters' speech and that of the narrator's we find endless shapes of these kinds of words (among them even some Turkish words), idioms, characteristic of the slang speech: "çorbë derrash" ("pigwash"), "medemek" ("which meand"), "with his vocabulary "allah-allah" ("oh my goodness"), "lëng groshe" ("worthless"), "e kishin kapur gafil" ("caught in the action"), "u këputa në mes"( "worn out"), "një më hu një më kërcu"("wandering around"), "pykë në diell" ("in vain"), " nuk më bën fajde" (doesn't work for me") etc, etc.

At the first observation it looks like there is no artistic function, as we have to do with a conversational language and has no literary value in it, but within this text the literary ,that is not representative, exists, but it existsin the liberation giving as well as in the fullfilment of that empty feeling that the author aims to present with its help. It looks like Keko is in love with the street language and conceously builds a new speech as a intertwinment of the simplified speech and less literary charm.

The simplified speech turns in Keko into magic that we would consider as an undisputable flow and his whole prose (especially his short narrations with which he made his entrance) is the fact of the overturning, the destroyal of the speechful way with which the Albanian literature was used.

For what was said above the literature of the author Teodor Keko, makes it a representation of the written verist model in the Albanian letters.

\section{References}

Talka Elda: Tradition and novelty the verist poetic, Rama Graf, Elbasan, 2011

Dado Floresha: Non-interpreted literature, Albanian world, Tiranë 2010

Çiraku Ymer: Critical observations from the history of the Albanian literature, Albas, Tiranë2011

Keko Teodor: The game, "Naim Frashëri", 1999

Keko Teodor:Made in Albania, "Albin"Tiranë 1998

Keko Teodor: Curriculum Vitae, selected narrations, "Toena", Tiranë 2008

The today's Albanian language dictionary, Tiranë, 1998

Jeferson Ann: Roby David, The modern literary theory , "Albas", 2006

11"R.D" newspaper, 22 March 1998,"...Today coldly judging this book, as if I was not the author, I guess it was there where the Albanian way of speaking of the 80 's entered for the first time." 